\title{
Stimulation of Consumer Cooperation Development in Small Forms of Fruits and Vegetables Production
}

\author{
Sergey Kalchenko ${ }^{1}$, Iryna Kolokolchykova ${ }^{1}$, Darya Legeza ${ }^{1}$, Denys Yeremenko ${ }^{1}$, \\ Andrii Hutorov ${ }^{2}$, Oleksandr Perederii ${ }^{3}$, Oleksandr Dorokhov ${ }^{4}$ \\ ${ }^{1}$ Dmytro Motornyi Tavria State Agrotechnological University, Melitopol, Ukraine \\ ${ }^{2}$ National Scientific Center Institute of Agrarian Economics, Kyiv, Ukraine \\ ${ }^{3}$ V.N. Karazin Kharkiv National University, Kharkiv, Ukraine \\ ${ }^{4}$ Simon Kuznets Kharkiv National University of Economics, Kharkiv, Ukraine
}

\begin{abstract}
The efficiency of small gardening is considered in this paper. The importance of peasant households for the Ukrainian village is justified.

The necessity measures facilitating the efficiency of family agricultural production was proved. The international practices of the functioning of peasant households were analyzed.

The recommendations such as the assessment of small agricultural development were proposed. The marketability level, its share in the revenue is the important criteria.

The necessity of the peasant households unions on cooperatives was proved. The servicing cooperative model was proposed. Its mission is a provision of sale of production.

Amendments in the efficiency of the economic activity, in budget of the farming families were determined.

The recommendations proposed enables to improve the peasants' well-being level, to influence positively on the vegetables market. Transition of peasant households to the entrepreneurial basis develop of servicing cooperation in small agricultural is presented as well.
\end{abstract}

DOI: 10.18421/TEM92-21

https://doi.org/10.18421/TEM92-21

Corresponding author: Oleksandr Dorokhov,

Simon Kuznets Kharkiv National University of Economics,

Kharkiv, Ukraine.

Email: aleks.dorokhov@meta.ua

Received: 20 February 2020.

Revised: 08 April 2020.

Accepted: 16 April 2020.

Published: 27 May 2020.

(cc) BY-NC-ND(C) 2020 Sergey Kalchenko at al; published by UIKTEN. This work is licensed under the Creative Commons Attribution-NonCommercial-NoDerivs 3.0 License.

The article is published with Open Access at www.temjournal.com
Keywords - peasant household, servicing cooperation, agricultural production.

\section{Introduction}

Present-day development of the agricultural sector of Ukrainian economy is characterized by extension of the process of agricultural producers' differentiation.

The field, procedural and institutional, territorial and social and economical characteristics are the criteria in such a case.

In particular, the nature of the functioning of a wide range of the field areas (dairy cattle breeding, fruit and vegetable growing, potato growing etc.) in the system of peasant households of Ukraine differs substantially according to the principles of its social and economic development from the same groups of agricultural production in European Union.

Transformation of system in the scope of social and economic, organizational, legal and ethical, and moral relations at the level of village areas defines the range of priorities during development and implementation of governmental initiatives as to the interests of the agricultural people themselves in the current context.

However, a substantial proportion of rural laborers are forced to work under conditions of self-survival.

Moreover, these agricultural producers are the inhabitants of rural settlements, and their economic activity is closely related to the processes of sustainable development of territorial communities.

That is exactly why the family-type agricultural enterprises are the important component in the field of agricultural production both in Ukraine and worldwide.

Their activity includes not only economic aspect, in particular, development of commercial products for commoditization of national food market.

This form of agricultural entrepreneurship is one of the ways of solution to problem of unemployment in 
a rural area, temporary suspension of depopulation process in the system of village areas.

In addition, there are no uniform official definition up till now which would unite such category of agricultural producers according to clear characteristics of criteria.

A great variety of notions meaning the representatives of the specified agricultural industry in the national regulatory field ("private peasant households", "agricultural households", "public households", "family farms" etc.) only confirm the necessity of improvement of categorial apparatus in this field.

Another important fact includes the absence of the officially approved indicators enabling to asses the performance of peasant households, taking into account their social and economic nature.

It is our opinion that the use of methods of assessment by which we can measure economical efficiency for business entities is unreasonable due to the fact that it does not take into account one of the substantial cost items - reimbursement of labor costs regarding peasant households members.

\section{Recent Research and Publications Analysis}

The range of problems comprising social and economic nature of peasant households functioning reflected in the papers of many scientists.

Theoretical and methodical foundations of functioning the family-type agricultural enterprises were researched in the papers [2], [3], and others.

Analyzing the courses of provision regarding the efficient functioning of peasant households, in particular, considered the establishment of servicing cooperatives as a mean of consolidation of resource potential of small agricultural formations and improvement of their competitive ability [9].

The notion which explains horizontal and vertical concentration with reference to agricultural production along with identification of positive and negative consequences of each process was formulated in this aspect [2].

Associations providing their members with the services in the field of processing and sale are the examples of successful activity of integrative entities of cooperative type.

The vertical concentration danger under conditions of present-day economical realities provides the control over the financial structures of activity among agricultural producers, i.e. all agricultural risks shall be imposed to the agricultural laborers, and the most of earnings shall be retained in banking sector, taking into account the consumer's economical strategy of large agricultural formations in relation to agricultural lands under conditions of present-day economical realities.
The researches [7], [13] deal with the social aspects of functioning of family-type households, as well as the influence of uneconomical components on their activity.

In particular, the importance of human factors' influence on the economic behavior within households, namely the nature of use of the available resource potential confirms the necessity of the mutual dependence comprising the level of energy consumption and the degree of social and economic activity of these entities, as well [4], [14].

It is our opinion that it is necessary to take into account the specified uneconomical components in the course of analysis of state's development and evaluation prospects for further activity within peasant households [5], [6].

Provisions of the theory of labor and consumer balance and model of "basic balance" which are the fundamental theoretical and methodological components in the course of research with regard to the nature of peasant households demonstrate convincingly the subjective evaluation nature of in the scope comprising the performance of functioning this sector of agricultural production on the part of its members-owners.

The issue of provision concerning the efficient development of small forms of agricultural production under present-day conditions was considered in papers [12], [17], and others.

So, in particular, we emphasized the importance of taking into account the prospects for commercial evolution of private peasant households of Ukraine as one of the priorities of state agricultural policy [10].

The problem of formation of layer of small agricultural entrepreneurship in the village in the realm of national economy remains unaddressed till now [11].

We shall specify that in [8] justified the necessity of the use of alternative evaluation methods of the performance results regarding peasant households, taking into account the social and economical nature of this sector of agricultural entrepreneurship.

In particular, he developed the system of indicators the analysis of which enables to determine the level of efficiency of the functioning of family-type agricultural enterprises.

We agree to the opinion which underlines the necessity of appropriate assessment on the performance results of peasant household, using only the standard procedures and indicators.

It is necessary to use the methodic tools enabling to prove not only the abstract efficiency of the use when it occupies resource potential in the realm of household. 
We think that justification of reasonability on the members' performance of any household in its economical activity is more important.

Proving clear synergies between the recommendations as to optimization of operational processes and level of agricultural people well-being is one of the methods.

\section{Materials and Methods of Research}

Provisions of theory without hired family and labor households formulated by the representatives of organizational and legal school were the theoretical and basic procedure of the research.

The nature of activity of peasant households is stipulated not only by the influence of the economical factors, but also by the special aspects of functioning concerning village family as a social unit according to them.

Moreover, the use of mostly own labor power in the course of manufacturing and business activity is an important special aspect of functioning of this form of agricultural production.

This fact stipulates a necessity of remuneration within corresponding labor expenditures, as well as taking into account of this circumstance during evaluation of the performance results of peasant household.

In [3] formulated the fundamental principles of business of the family and labor household in the field of agricultural production, having justified the combination comprising the influence of economical and social factors on its development.

The following basics are separated from the fundamental basic of functioning: labor and consumer balance as a motivational incentive to production and commercial activity, and the criterion of assessment of the performance of labor resources expenditures; model of "basic balance" as a form of interrelation between labor put in and the effect achieved; sinusoidal nature of household development as a result of the physiological essence of peasant family and its further establishment.

Taking into account the necessity of alternative evaluation of the efficiency level of the family forms of agricultural production, we propose to use the following indicators:

$$
\begin{aligned}
& V D=V-Z v \\
& C D u=V D-Z p l u,
\end{aligned}
$$

where $V D$ is a gross income, $V$ is receipts from sales, $Z v$ is production expenditures, $C D u$ is contingent net income, Zplu is contingent salary [9].

It should be noted in this aspect that there is a necessity of appropriate monetary valuation of the physical labor expenditures among peasant household members.

The following approaches may be used as the options for the valuation: monetization of the amount of men/hours spent, predetermined amount of remuneration for labor activity etc.

The possibility of existence of social and economic units which may function using the agricultural industry as an additional source of cash and other proceeds is an important special aspect of presentday state regarding the development of peasant households.

The valid system of social protection of citizens provides elderly agricultural people with a certain minimum of resources, which enable them to reduce the level of intensity of labor activity.

At the same time, it should be noted that the differences in the principles of arrangement comprising business activity stipulate the necessity of differentiated approach in the development of recommendations as to the improvement of the efficiency of functioning of small forms of agricultural production.

We propose their following classification for the purpose of more detailed study and adding the special aspects of economical activity of peasant households.

The first is Commercial Economies.

Results of production activity are specified exclusively for further implementation, in which the share of the products consumed is at minimum.

Agricultural laborers make active use of the innovative design and engineering means, potentially ready to participate in the establishment of inter-farm associations of cooperative and corporate type as the initiators of the corresponding projects.

The small farming enterprises, as well as the private entrepreneurs employed in the agricultural business shall be ascribed to them from a regulatory and legal perspective.

The second is Subsistence and Commercial Economies.

The agricultural products manufactured shall be held both for sale and satisfaction of consumption requirements within this peasant family.

In such a case, it should be noted that both the close relatives (father, mother, and children) and the extended scope of persons combined with the use of inter-institutional family communication shall be ascribed to the family members.

The households of this type make active use of labor saving tools due to the fact that the expenditures for their maintenance shall be compensated for cash proceeds from the sales.

Moreover, the peasant families from specified group are potentially ready to participate in the activity of the servicing cooperative depending from 
the level of marketability regarding the products manufactured.

The third is Subsistence Economies.

Satisfaction of own food products is a principal aim of the production activity in the field of agricultural production; only surplus not consumed or certain kinds of products (mostly fruits) shall be sold.

Own labor power is used mostly; the mechanical equipment are applied at a minimum.

The representatives of this category of peasant households may participate in the activity of cooperative associations. However, they are not the active members.

Therefore, the interrelatedness of the amount of family budget, the monetary equivalent of the manufactured and sold products is one of the essential indicators reflecting the nature of peasant household functioning and its typology.

Taking into account the importance of consideration the influence of the results on agricultural production as the total amount of proceeds of the rural family, it was proposed to use the following formula:

$$
P i=B i / D z * 100
$$

where $P i$ is a share of other kind of products in the household income, $B i$ is a total value of other kind of products, $D z$ is a total amount of household income.
The use of labor resources by the members of the peasant households in the course of own economic activity shall be compensated by means of result achieved.

Further existence of this sector of agricultural production is possible only under these circumstances.

We think that in its turn, provision of peasant households' development on the principles of extended reproduction is one of the integral components of the process of development of both an agricultural industry and the rural areas.

\section{Results and Discussion}

Growing of perennial plantings is an efficient way to implement business activity for family forms involved in agricultural business.

It should be noted that the gardening is also included into the priority kind within agricultural production gathering the farming enterprises in the countries of European community.

The share of this industry course in Spain, Italy and France was equal averagely to more than $60 \%$ within 2012-2016, and this share exceeded $85 \%$ for France (Fig. 1).

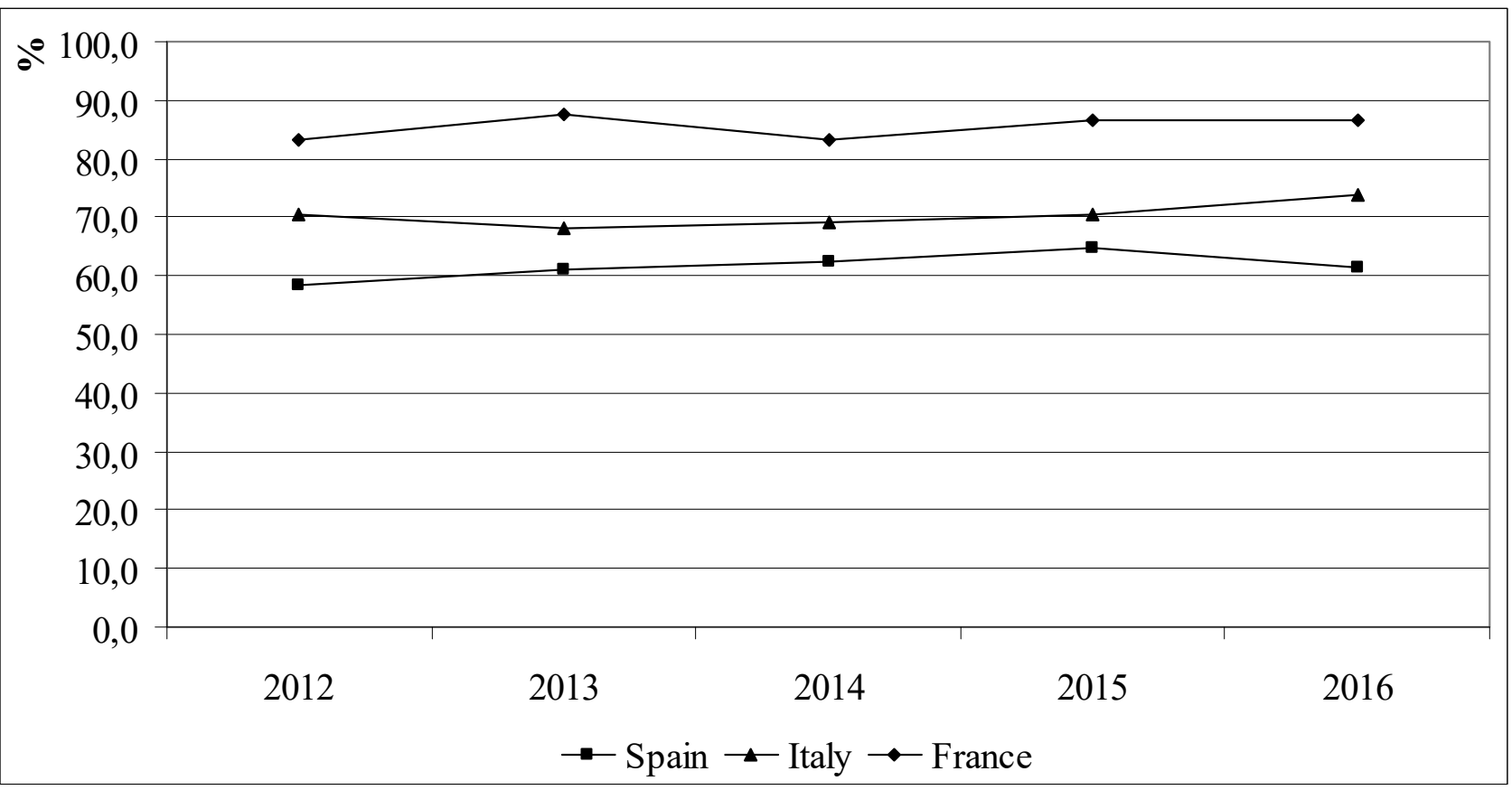

Figure 1. Share of fruits and vegetables in the structure of agricultural production of the farming enterprises of the countries of European Community, \%

Source: developed by authors according open data sourses 
This practice is essential to the realities of the Ukrainian economy, taking into account the role of peasant households in grouping of the national market of fruit-and-vegetables raw materials.

Analysis of the dynamics of share that occupy peasant households in Ukraine, in the total volume of basic kinds of products of plant growing and animal products, provides strong evidence that the role of representatives in this sector of agricultural production is extremely important.

So, in particular, the highest value is observed in potato growing and honey production (98\%), vegetable growing and sheep breeding (86\%), vegetable growing $(85 \%)$, gardening $(82 \%)$ and milk production (75\%) (Fig. 2).

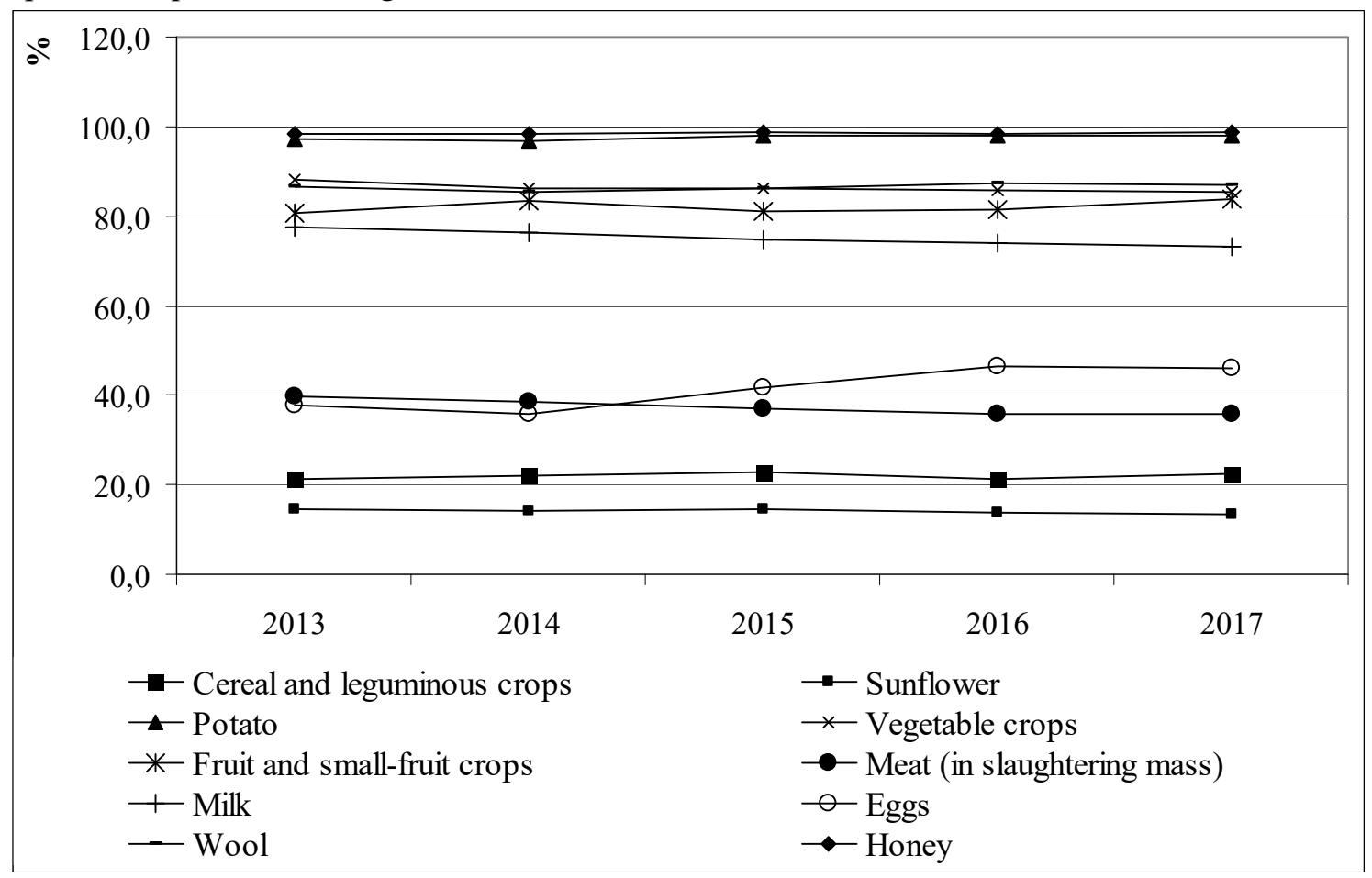

Figure 2. Share of peasant households of Ukraine in total structure of agricultural producers, \% Source: calculated by the authors on the basis of data [15]

The reasons of this situation include the concentration of entrepreneurial activity of large agricultural enterprises in the industry courses providing the use of considerable volumes of material resources, buildings and structures as an integral component of the production process.

Another factor includes the efforts of this group of manufacturers of agricultural products to maximize the level of the efficiency of land resources use.

That is why large agricultural formations mostly do not use in their activity the lands of pasture (dairy cattle breeding) and demonstrate the low level of activity in the gardening.

The agricultural enterprises of various types are the fundamental entities on the market products of gardening industry.

So, 2571 thousand tons of fruits and vegetables were produced in 2018, where 2014.7 thousand tons are accounted for households of the citizens, and this is more than $78.4 \%$ [16].

It is evidence that the defining role belongs to peasant households in this segment of agricultural sector in the Ukrainian economy.
This trend is observed also according to the indicator of areas of fruit and berry plantations, which were equal to 227.9 thousands of hectares in total for Ukraine, where 159 thousands of hectares are accounted for households of the citizens, which is equal to more than $69.8 \%$ (Fig. 3).

As to the qualitative characteristics of the efficiency of production of fruit and berry crops, we can also see the advantages of the very households among the citizens.

The level of average crop yield of these products for the entirety of the researched period in this group of agricultural laborers is higher than in the agricultural enterprises and private farms.

So, the average level of yield of fruit and berry crops in Ukraine was equal to 128.4 centners/hectare in 2018 , it was equal to 106.2 centners/hectare in agricultural enterprises; it was equal to 112.9 centners/hectare in private farms, and it was equal to 136.3 centners/hectare in households of citizens [16].

Taking into account the fact that the gardening is the least financially cost-based project for agricultural people, we developed the project for 
servicing cooperative which functioning is based on the very these industrial courses (fig. 4).

The peasant households are consolidated in the event of horizontal concentration for the cooperative organization establishment, which will lead to further protection of own economic interests [1], [10].

That is why the establishment of cooperative servicing is one of the few measures on the behalf of positive effect which is evident for all groups of households.

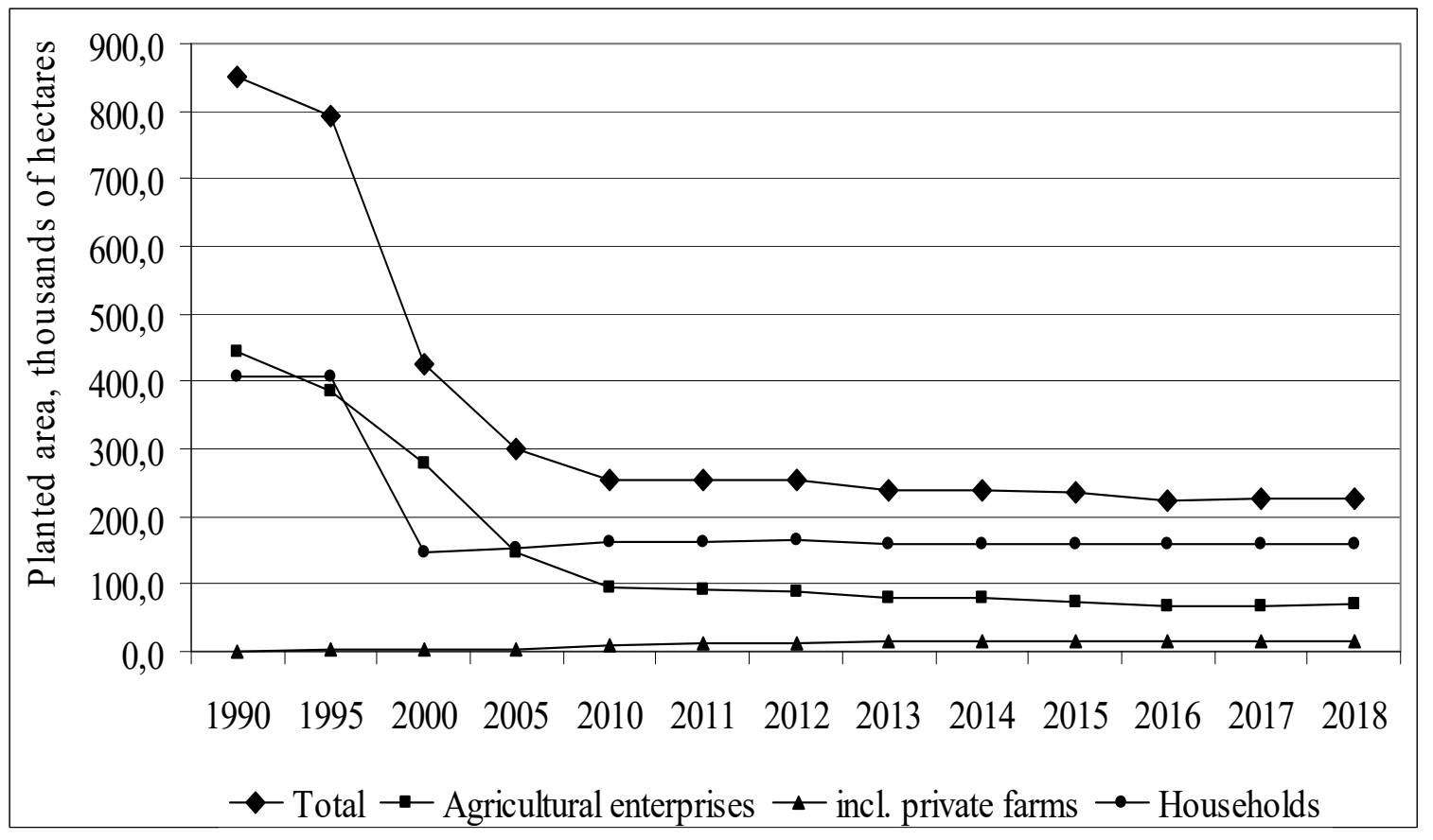

Figure 3. Dynamics of planted areas of fruit and berry crops in Ukraine Source: calculated by the authors on the basis of data [16].

For this purpose we developed the model of sales cooperative the activity of which we shall be focused on the achievement of not only economical, but also the social goals.

The list of economic priorities include the provision of the efficient sale of agricultural products from all members, and increase the level to marketable value of products of the very households; the social priorities include the improvement of level of well-being of peasant community.

The peasant households of Steppe area of Ukraine were selected as the subjects of research.

According to the data of regional administration of statistics, around 126.8 thousands of peasant households perform within the territory of one region of Steppe area.

According to the results of anonymous questionnaire survey conducted among the representatives of this segment of agricultural production, the share of households within commercial group is equal to $24.8 \%$, subsistence and commercial group - $58.6 \%$, subsistence group $16.6 \%$.

Taking into account the special aspects of natural and climatic conditions of the region, as well as the state of development of market' elements infrastructure, in particular, the logistic system, we propose the differentiated approach as to the recommendation of strategy regarding the economic activity of each group of households.

So, in particular, we propose cultivation of fruits and vegetables for the households for commercial and subsistence and commercial groups, due to the fact that this industrial sector is slightly explored by the large agricultural enterprises (table 1).

This model provides the phased transition from cultivation of vegetable products to gardening specialization.

Its specific nature resides in the gradual allocation of lands for perennial plantings, preserving certain areas for vegetables for the purpose of obtainment and the possibility of compensation for expenditures related to the implementation of this project.

Starting from 6th year, the garden goes to the phase of production facilities step-by-step, and the peasants minimize their efforts in the field of vegetable production.

The contingent level of products profitability will be equal to $260 \%$ in 10 years, when fruit trees will achieve their full productive maturity. 


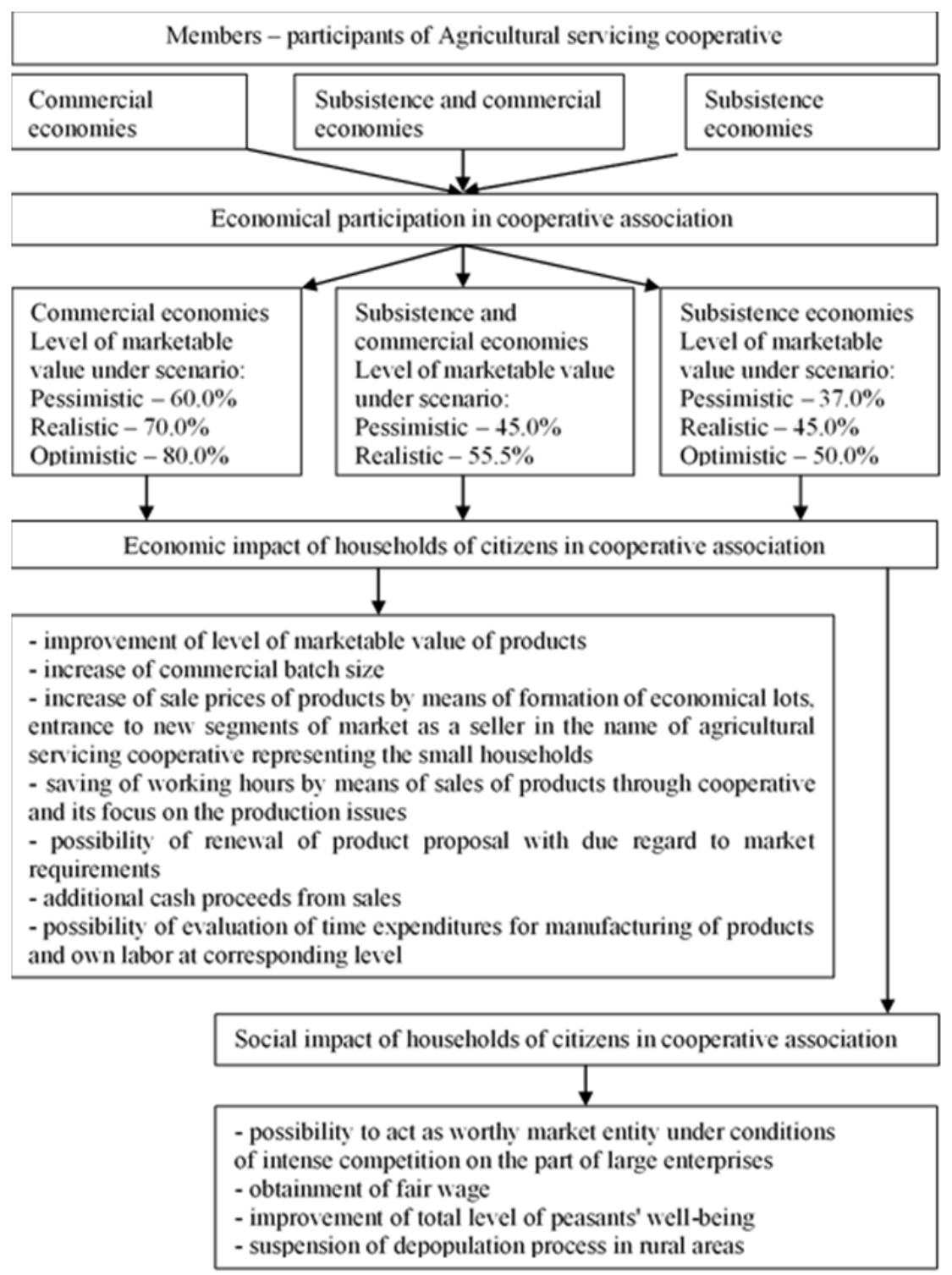

Figure 4. Model of agricultural servicing cooperative Source: development by the authors

Table 1. The production mode of peasant households of commercial and subsistence and commercial types of fruit/berry sector, euro/ha

Source: development by the authors.

*Taking into account the monetary evaluation of labor expenditures

\begin{tabular}{|c|c|c|c|c|c|}
\hline \multirow{2}{*}{ Indicators } & \multicolumn{4}{|c|}{ Year } & \multirow{2}{*}{$\begin{array}{c}\text { Averagely } \\
\text { within } 10 \text { years }\end{array}$} \\
\hline & 1 & 3 & 5 & 10 & \\
\hline Production expenditures, total & 1214,48 & 1176,1 & 1145,32 & 1186,36 & 972,8 \\
\hline \multicolumn{6}{|l|}{ including } \\
\hline Material expenditures & 146,3 & 172,14 & 231,04 & 308,18 & 216,22 \\
\hline Contingent salary* & 1068,18 & 1003,96 & 913,9 & 878,18 & 757,72 \\
\hline Proceeds from sales & 2662,66 & 2962,86 & 4069,42 & 4279,56 & 3207,96 \\
\hline Gross income & 2516,36 & 2791,1 & 3838,38 & 3969,48 & 2990,6 \\
\hline Contingent gross income & 1448,18 & 1784,48 & 2924,48 & 3091,3 & 2232,5 \\
\hline Contingent level of profitability, $\%$ & 119,24 & 151,75 & 255,38 & 260,61 & 229,22 \\
\hline
\end{tabular}

type households due to the fact that this sector enables the

We think that concentration on cultivation of pome and stone fruits is also acceptable for subsistence- use relatively small areas of agricultural lands without active use of mechanical equipment and industrial automation (table 2). 
Table 2. The production mode of peasant households of subsistence type of fruit and berry sector, euro/ha Source: development by the authors. (*Taking into account the monetary evaluation of labor expenditures)

\begin{tabular}{|c|c|c|c|c|c|}
\hline \multirow{2}{*}{ Indicators } & \multicolumn{2}{|c|}{ Actual data } & \multirow{2}{*}{ Project } & \multicolumn{2}{c|}{ Project, +- (before) } \\
\cline { 2 - 5 } & $\mathbf{2 0 1 8}$ & $\begin{array}{c}\text { Averagely within } \\
\mathbf{2 0 1 5 - 2 0 1 8}\end{array}$ & & $\mathbf{2 0 1 8}$ & $\begin{array}{c}\text { Average } \\
\text { value }\end{array}$ \\
\hline Production expenditures & 2,03 & 2,01 & 1,80 & $-0,23$ & $-0,21$ \\
\hline Including & & & & & \\
\hline Material expenditures & 0,23 & 0,22 & 0,48 & 0,25 & 0,25 \\
\hline Contingent salary & 1,80 & 1,79 & 1,33 & $-0,48$ & $-0,46$ \\
\hline Earnings, UAH & 1,35 & 1,33 & 3,04 & 1,69 & 1,71 \\
\hline Gross income & 1,12 & 1,11 & 2,57 & 1,45 & 1,46 \\
\hline Contingent gross income* & $-0,68$ & $-0,68$ & 1,25 & 1,92 & 1,92 \\
\hline Contingent level of profitability, \% & $-33,5$ & $-33,6$ & 69,2 & 102,7 & 102,8 \\
\hline Level of marketable value, \% & 39,6 & 39,9 & 52,3 & 12,7 & 12,4 \\
\hline
\end{tabular}

It enables to use moisture in the area of risky agriculture more reasonably, and on the other part it will influence on the total amount of material expenditures slightly. At the same time, the implementation of the measures proposed enables them to reduce the physical labor expenditures substantially, which will have the positive impact on the level of production efficiency, as well as it will stimulate the active use of this business model by peasants who use the small land areas $(0.1-0.12 \mathrm{ha})$. Its practical implementation will not only compensate completely for the labor outlays and labor input, but also it will enable obtaining considerable cash proceeds.

The last fact will have a positive impact on the level of well-being of national peasant class and it will improve the social climate in rural regions.

Model of participation of small economic entities in cooperative activity was proposed by us on the basis of economic calculations of reasonability and return on the expenditures, related to the establishment and functioning of agricultural sales servicing cooperative, and the economic impact from sales of fruit products through cooperative.
Model is aimed at such basic indicators influencing on the profitability of business of commercial-type small enterprises, as well as the profit-making capacity of subsistence, commercial and subsistence households: consolidated efforts of all participants and clear fulfillment of obligations.

The model of participation of peasant households in sales cooperation considers the following basic indicators: total area of fruit plantations 20 ha, average yield of stone and pome fruits in Steppe area within $2018-10.8 \mathrm{t} / \mathrm{ha}$, actual and projected sale prices fixed according to data of sales market of certain products in compliance with their territorial location. Prediction calculations of sales cooperation model on the fruit market by peasant households comprising three types which are represented in Tables 3-5.

The implementation of this project will enable to amend the nature of business activity for primary majority of peasant households in some way.

In particular, obtainment of the following results is predicted according to pessimistic, realistic and optimistic scenario (table 3 ).

Table 3. The production and sales model of servicing cooperative for peasant households of commercial type Source: development by the authors. (*Taking into account the monetary evaluation of labor expenditures)

\begin{tabular}{|l|c|c|c|c|}
\hline \multicolumn{1}{|c|}{ Indicators } & Actual data & Pessimist scenario & Realist scenario & Optimistic scenario \\
\hline Number of households, units & 6 & 6 & 6 & 6 \\
\hline Land area, ha & 12 & 12 & 12 & 12 \\
\hline Cost of goods manufactured, ths.euro & 15,9 & 15,9 & 24,4 & 35,3 \\
\hline Proceeds from sales, ths.UAH & 26,4 & 26,4 & 34,9 & 44,1 \\
\hline Production expenditures, ths.euro & 2,6 & 1,9 & 1,9 & 1,9 \\
\hline Contingent salary, ths.euro* & 9,1 & 8,2 & 8,2 & 8,2 \\
\hline Gross income, ths.euro & 23,9 & 24,5 & 32,9 & 42,2 \\
\hline Contingent net profit, ths.euro & 14,8 & 16,3 & 24,7 & 34,0 \\
\hline Contingent level of profitability, \% & 126,3 & 161,1 & 244,1 & 335,6 \\
\hline Level of marketable value, \% & 60,0 & 60,0 & 70,0 & 80,0 \\
\hline Families income, ths.euro & 31,5 & 31,5 & 40,0 & 50,9 \\
\hline $\begin{array}{l}\text { Share of agricultural products } \\
\text { in total family income, \% }\end{array}$ & 50,4 & 50,4 & 61,0 & 69,3 \\
\hline
\end{tabular}


Sales of fruits by commodity-type peasant households are profitable today. According to the actual data, at the level of marketable value equal to 60.0 the households receive 388.4 thousands of UAH of net income and the contingent level of profitability is equal to $126.3 \%$.

Under the conditions of joining a servicing cooperative for fruit sales, the peasant households will be able to get 3 different effects under pessimistic, realistic and optimistic scenarios.

Based on the pessimistic scenario, the commercial economies will sell fruits with a $60.0 \%$ profitability level and at the same price as their own household.

However, by reducing the costs of sales and transferring them to the costs of the cooperative, the peasant households will receive 16.3 thousands of euros of contingent net income and the contingent level of profitability equal to $161.1 \%$. It is proposed to raise the level of marketable value to $70.0 \%$ and
$80.0 \%$ under the conditions of the realistic and optimistic scenario.

This will enable to form optimal batches of products and to sell them at higher prices. The total contingent net income of these scenarios will be equal to 24.7 thousands of euro and $244.1 \%$ and 34 thousands of euro and $335.6 \%$ respectively.

Another important indicator that proves the feasibility of labor participation of the members owners in the project is the impact of the outputs on the total income. In the event of practical implementation of the proposed measures, they can meet the needs of households by means of production results by $70 \%$.

Sales of fruits by peasant households of subsistence and commercial type at the level of marketable value of $45 \%$ enable to receive 3.6 thousands of euros of net income, with the contingent level of profitability being $69.3 \%$ (Table 4).

Table 4. The production and sales model of servicing cooperative for peasant households of subsistence and commercial type

Source: development by the authors. (*Taking into account the monetary evaluation of labor expenditures)

\begin{tabular}{|l|c|c|c|c|}
\hline \multicolumn{1}{|c|}{ Indicators } & Actual data & Pessimist scenario & Realist scenario & Optimistic scenario \\
\hline Number of households, units & 10 & 10 & 10 & 10 \\
\hline Land area, ha & 5,3 & 5,3 & 5,3 & 5.3 \\
\hline Cost of goods manufactured, ths.euro & 3,9 & 3,9 & 6,7 & 8,8 \\
\hline Proceeds from sales, ths.UAH & 8,7 & 8,7 & 12,1 & 14,6 \\
\hline Production expenditures, ths.euro & 1,1 & 0,9 & 0,9 & 0,9 \\
\hline Contingent salary, ths.euro* & 4,0 & 3,6 & 3,6 & 3,6 \\
\hline Gross income, ths.euro & 7,6 & 7,9 & 11,2 & 13,7 \\
\hline Contingent net profit, ths.euro & 3,6 & 4,3 & 7,6 & 10,1 \\
\hline Contingent level of profitability, \% & 69,3 & 95,3 & 170,7 & 226,4 \\
\hline Level of marketable value, \% & 45,0 & 45,0 & 55,0 & 60,0 \\
\hline Families income, ths.euro & 34,7 & 34,7 & 43,3 & 54,2 \\
\hline $\begin{array}{l}\text { Share of agricultural products } \\
\text { in total family income, \% }\end{array}$ & 45,7 & 45,7 & 56,4 & 65,2 \\
\hline
\end{tabular}

Considering the pessimistic scenario, the subsistence and commercial economies will sell fruits with a profitability level of $45.0 \%$ and at the same price as in their own households.

However, by reducing the sales costs and transferring them to the costs of the cooperative, the peasant households will receive 4.3 thousands of euros of contingent net income and a contingent level of profitability of $95.3 \%$.

It is proposed to raise the level of marketable value to $55.0 \%$ and $60.0 \%$ under the conditions of the realistic and optimistic scenario.

This will enable forming optimal batches of products selling them at higher prices. The total contingent net income of these scenarios will be equal to 7.6 thousands of euros and $170.7 \%$ and 10.1 thousands of euros and $226.4 \%$ respectively.

It should also be noted the significant impact of economic performance on the well-being of its members. In the event of the optimistic scenario, it is projected that the peasants' existing needs can be met by $65.2 \%$.

The most difficult situation today is the situation with the sale of fruits by the subsistence economies.

They are aimed at consumption products according to their nature, and their inability to move to the commercial and subsistence economies is due to the fact that the conditions of sale are very difficult. The following effect can be obtained due to involvement of these households into cooperative association and the ability to sell products at market prices, while reducing the cost of sales.

The sale of fruits by the subsistence-type peasant households is partly unprofitable according to the actual indicators of production and sales activities.

If we take into account the structure of costs labor costs according to design indicators, we can see that the contingent net loss is equal to 1.2 thousands of euros, and the contingent loss rate is equal to $37.0 \%$ (Table 5). 
Table 5. The production and sales model of servicing cooperative for peasant households of subsistence type Source: development by the authors. (*Taking into account the monetary evaluation of labor expenditures)

\begin{tabular}{|l|c|c|c|c|}
\hline \multicolumn{1}{|c|}{ Indicators } & Actual data & Pessimist scenario & Realist scenario & Optimistic scenario \\
\hline Number of households, units & 15 & 15 & 15 & 15 \\
\hline Land area, ha & 2,7 & 2,7 & 2,7 & 2,7 \\
\hline Cost of goods manufactured, ths.euro & 1,4 & 1,4 & 2,3 & 3,1 \\
\hline Proceeds from sales, ths.UAH & 3,7 & 3,7 & 5,0 & 6,2 \\
\hline Production expenditures, ths.euro & 1,3 & 0,6 & 0,6 & 0,6 \\
\hline Contingent salary, ths.euro* & 3,6 & 3,0 & 3,0 & 3,0 \\
\hline Gross income, ths.euro & 2,4 & 3,1 & 4,4 & 5,6 \\
\hline Contingent net profit, ths.euro & $-1,2$ & 0,1 & 1,4 & 2,6 \\
\hline Contingent level of profitability, \% & $-24,5$ & 2,2 & 40,1 & 73,0 \\
\hline Level of marketable value, \% & 37,0 & 37,0 & 45,0 & 50,0 \\
\hline Families income, ths.euro & 17,4 & 17,4 & 18,3 & 19,2 \\
\hline $\begin{array}{l}\text { Share of agricultural products } \\
\text { in total family income, \% }\end{array}$ & 7,8 & 7,8 & 12,4 & 16,2 \\
\hline
\end{tabular}

If the remuneration for own labor is not taken into account in the cost structure, then it seems that these households sell products with profit.

However, justifying the need for an appropriate assessment of own labor by peasant households of all types, the calculation of the three scenarios yielded positive results. Thus, in the pessimistic scenario of the participation of subsistence economies in the sales cooperation, the contingent net profit will be equal to 0.1 thousands of euros, and the contingent level of profitability will be equal to $2.2 \%$.

This is possible subject to sales of products with a level of marketable value equal to $37.0 \%$. It is proposed to raise the marketable value level to $45.0 \%$ and $50.0 \%$ under conditions of the realistic and optimistic scenario. This will enable the servicing cooperative to form optimal batches of products and to sell them at higher prices.

The total contingent net profit of these scenarios will be equal to 1.4 thousands of euros and $40.1 \%$ and 2.6 thousands of euros and $73 \%$ respectively.
Considering the impact of the results of this project implementation on the level of well-being of members within subsistence economies, the following circumstances should be noted.

The vast majority of peasants who carry out the production and business activities in a suitable way simply do not have the physical ability to perform the exhausting labor operations.

These are elderly people who are forced to engage in agricultural production.

The increase in the impact of the results of the activities on the level of family well-being more than twofold is a significant factor for such individuals. It should also be noted that the proposed recommendations provide a reduction in the cost of manual labor in their technical and technological aspect through the mechanization of the processes involved.

The total economic impact of the sale of fruit products by the peasant households in the Steppe area at the rate of 20 ha is presented in Table 6.

Table 6. Economic impact from the implementation of model of servicing cooperative on sales of fruits for peasant households of all types

Source: development by the authors. (*Taking into account the monetary evaluation of labor expenditures)

\begin{tabular}{|l|c|c|c|c|}
\hline \multicolumn{1}{|c|}{ Indicators } & Actual data & Pessimist scenario & Realist scenario & Optimistic scenario \\
\hline Number of households, units & 31 & 31 & 31 & 31 \\
\hline Land area, ha & 20,0 & 20,0 & 20,0 & 20,0 \\
\hline Cost of goods manufactured, ths.euro & 21,2 & 21,2 & 33,3 & 47,2 \\
\hline Proceeds from sales, ths.UAH & 38,9 & 38,9 & 52,0 & 64,9 \\
\hline Production expenditures, ths.euro & 5,0 & 3,4 & 3,4 & 3,4 \\
\hline Contingent salary, ths.euro* & 16,7 & 14,8 & 14,8 & 14,8 \\
\hline Gross income, ths.euro & 33,8 & 35,4 & 48,6 & 61,5 \\
\hline Contingent net profit, ths.euro & 17,1 & 20,7 & 33,8 & 46,8 \\
\hline Contingent level of profitability, $\%$ & 78,9 & 113,5 & 185,8 & 256,9 \\
\hline Level of marketable value, $\%$ & 54,4 & 54,4 & 64,1 & 72,6 \\
\hline Families income, ths.euro & 83,6 & 83,6 & 101,6 & 124,2 \\
\hline $\begin{array}{l}\text { Share of agricultural products } \\
\text { in total family income, } \%\end{array}$ & 25,3 & 25,3 & 32,8 & 38,0 \\
\hline
\end{tabular}


According to the final calculations, the peasant households of all types today actually sell the marketable products of the gardening industry with a marketable value level of $54.4 \%$, receiving 17.1 thousands of euros of contingent net profit and $78.9 \%$ of the contingent level of profitability.

Given the use of sales cooperation in the sale of products, the calculation model shows that the level of marketable value will increase from $54.4 \%$ to $72.6 \%$.

The realistic scenario shows a marketable value level of $64.1 \%$, a contingent net profit of 33.8 thousands of euros, and a contingent level of profitability of $185.8 \%$.

The optimistic scenario will raise the contingent profitability level to $256.9 \%$.

Analyzing the nature of the impact of the results of activity of the sales cooperative on the level of wellbeing of the peasant class, the following circumstances should be noted.

Firstly, a significant percentage of the cooperative members are accounted for by the subsistence-type households, which are physically incapable of engaging in manufacturing of agricultural products to the full extent.

Consequently, their income is based on the payments from the state budget (pensions, subsidies, etc.). This situation is objective for the contemporary realities of the national village and cannot be disregarded.

That is why this figure is equal to $38 \%$ in general although we observed a significant increase in the impact of production results on the amount of the family budget of the commercial and subsistence economies $(65-70 \%)$.

Secondly, the purpose of this particular cooperative is to organize the sale of agricultural products grown by its members.

The list of tasks to be solved within this organization does not include, in particular, the provision of services for the execution of technological operations (soil cultivation, fertilization, treatment of plants with plant protection agents etc.).

We have assumed that the establishment of a sales cooperative is an objective necessity and a compulsory consequence of the increase in production for each peasant household.

It is expected a further extension of the list of services which a cooperative organization will provide to its members in order to reduce the amount of cost of labor outlays and labor input.

Thirdly, the relatively small use of labor resources and land area and, as a consequence, the amount of earnings and the contingent net profit are stipulated by the number of households.
The best possible number of members for a successful start of the servicing cooperative should be equal to 20-25 members, where at least $20 \%$ should come from business entities.

Further increase in the number of the cooperative members is a result of the successful activity of this organization.

Taking into account the complex social and economic situation which is characteristic of the current realities of the countryside, we plan to involve only representatives of the economically active part of the rural community at the stage of establishment.

Another fact in favor of the use of small land areas (20 hectares) is the projected negative consequences of the liberalization of land relations.

One of the reasons for the high performance of agricultural enterprises in the field of gardening is the underestimation of the main means of agricultural production, soil, and, consequently, the low amount of rent.

As a result of the inclusion the agricultural land in the system of goods/money relationship, the corresponding payments will increase substantially and the problem of the efficient use of land areas in agricultural production will become quite acute.

Thus, we can see that the proposed recommendations have not only economic but also a social effect.

Well-being growth as a real result of practical implementation of measures to optimize the system of production and business relations in the system of peasant households will stimulate an increase in the commodity share in this segment of agricultural entrepreneurship.

The revival of cooperative construction on the basis of small agrarian forms will facilitate the process of institutionalization of the family agrarian business.

In its turn, the transformation of the peasant households into a full-fledged entity and a participant of social and economic relations at the level of the Steppe area will enable to accelerate the process of decentralization of rural communities.

\section{Conclusions}

The importance of the peasant households as a subject of the national system of agricultural production and the specific component of social and economic relations at the level of rural territories is substantiated during the research.

The importance of optimization of theoretical and methodological approaches to the analysis of the current state and substantiation of the further prospects for the development of this group of agricultural producers was justified. 
The scientific approaches for classification peasant households according to the nature of their economic activity performance were formulated.

The necessity for development of practical recommendations as to optimization of the system, which comprises organizational and economic relations on the basis of peasant households is proved.

The models of development the gardening industry as the most profitable for different types of peasant households (commercial, subsistence and commercial and subsistence) were offered.

It provided the active involvement of labour saving tools and the reduction of manual labor costs. The practical implementation of the recommendations should result in an increase in the level of yield of perennial plantings, as well as a decrease in the degree of exhaustion of the production process for peasants.

It was established that the practical implementation of the proposed measures will significantly increase the level of industry development efficiency, and these measures will have a positive impact on the amount of income among the rural population.

\section{References}

[1]. Chayanov, A. (2019). A Short Course on Cooperation. Peasant Studies, 4(2), 8-56. https://doi.org/10.22394/2500-1809-2019-4-2-8-56

[2]. Chayanov, A. V. (1966). The theory of peasant economy, ed. D. Thorner, B. Kerblay, and REF Smith. Homewood, Ill., USA: Irwin.

[3]. Chelyntsev, A. N. (1919). Teoreticheskiye osnovaniya organizatsii krest'yanskogo khozyaystva.[Theoretical foundations of the organization of a farm]. Khar'kov.

[4]. Gontareva, I., Streimikiene, D., Ivanenko, O. (2015). Theoretical Background and Problems of Energy Efficiency in Ukraine. Transformations in Business \&Economics, 14(35A), 563-583.

[5]. Hutorov, A. O., Lupenko, Y. O., Posylaiev, V. V., Dorokhov, O. V., \& Yermolenko, O. A. (2019). Economic basis of forming and implementation of the biofuel production potential in Ukraine. Bulletin of the Transilvania University of Brasov. Forestry, Wood Industry, Agricultural Food Engineering. Series II, 12(1), 43-58.
[6]. Hutorov, A. O., Yermolenko, O. A., Lupenko, Y. O., \& Dorokhov, O. V. (2018). Strategic management of the agrarian sector of economy based on the analysis of value chains. Bulletin of the Transilvania University of Brasov. Forestry, Wood Industry, Agricultural Food Engineering. Series II, 11(2), 101114.

[7]. Josifidis, K. O. S. T. A., Supić, N., Beker Pucar, E., \& Srdić, M. (2012). The welfare regimes and relative poverty in the EU-14. 1995-2006. International Journal of Economic Research, 9(2), 297-319.

[8]. Kalchenko, S. (2013). Current development prospects of farm housesholds. Actual Problems of Economics, 12(150), 147-152

[9]. Kalchenko, S., Yeremenko, D., \& Hrybova, D. (2018). Features of the use of resource potential in peasant farms. Baltic Journal of economic studies, 4(4), 140-144.

[10]. Marx, K., \& Engels, F. (1989). Collected works (Vol. 31). International Publishing Company Incorporated.

[11]. Mishenin, Y., Valentynov, V., Maslak, O., Koblianska, I. (2017). Modern transformation in small-scale agricultural commodity production in Ukraine. Marketing and management of innovation, 4, 358-366.

[12]. Shanin, T. (1973) The Nature and Change of Peasant Economies. Sociologia Ruralis. 13(2), $139-171$.

[13]. Shuba, B., \& Sotskyi, A. (2019). World experience in financing innovative small businesses. Baltic Journal of Economic Studies, 5(1), 239-244.

[14]. Simanaviciene, Z., Virgilijus, D., \& Simanavicius, A. (2017). Psychological factors influence on energy efficiency in households. Oeconomia Copernicana, 8(4), 671-684.

https://doi.org/10.24136/oc.v8i4.41

[15]. Sil's'ke hospodarstvo Ukrayiny 2017: statystychnyy zbirnyk (2018). [Agriculture of Ukraine 2017: Statistical collection] [in Ukrainian].

[16]. Prokopenko, O. M. (2015). Roslynnytstvo Ukrainy: Statystychnyi zbirnyk. K.: Derzhavna sluzhba statystyky Ukrainy.

[17]. Varchenko, O., Svynous, I., Grynchuk, Y., Tkachenko, K., \& Shust, O. (2018). The strategy of developing agricultural supply chain in terms of food security in Ukraine. Int. Journal of Supply Chain Management, 7(5). 657-666. 